\title{
On some of the basic trends in Russian higher education in the context of transition to education for sustainable development
}

\author{
Marina Nikiforova* \\ Ural State University of Economics, 8 Marta/Narodnoy Voli St. 62/45, 620144 Ekaterinburg, Russia
}

\begin{abstract}
The paper discusses the basic trends in the system of Russian higher education in the light of transition to the model of education for sustainable development. Special attention is given to some tendencies in language teaching in institutions of higher education, humanitarian focus of higher education being emphasized.
\end{abstract}

\section{Introduction}

The concept of sustainable development, adopted in 1992 in Rio de Janeiro at the UN Conference, is becoming an increasingly relevant subject at various international and regional forums and conferences, determining to a large extent the direction of scientific, technical and socio-political thought in the third Millennium. Understanding of the global problems and their consequences (environmental disasters, economic recessions, socioeconomic inequality, problems in healthcare, etc.) that people faced in the 20 th century and still face in the 21 st century, forces the human society to invent new ways of preserving the civilization and the biosphere, to search for the possibility of harmonious co-existence and co-evolution of the human society and nature.

The concept of sustainable development is traditionally described as a triad of economic, ecological and social constituents, education being one of the most significant components of the social subsystem. The UNESCO website notes that UNESCO organization "aims to improve access to quality education on sustainable development at all levels and in all social contexts, to transform society by reorienting education and help people develop knowledge, skills, values and behaviours needed for sustainable development" [1]. In this regard, a number of scholars (I. V. Ilyin, A.D. Ursul, and T. A. Ursul et al.) state that it is education as a powerful tool of forming an individual and society on the whole that can ensure an effective and painless transition from the unstable society with its technocracy and consumerism to a society of sustainable development [2]. And thus, it is education that should become a major priority for national governments, legal authorities and world organizations.

It is evident that transition of the entire education system to the new model of education for sustainable development requires an appropriate legal framework, which should include the introduction of sustainable development ideas in education standards, the integration of

\footnotetext{
* Corresponding author: armada29@yandex.ru
} 
sustainable development principles in the content of study programmes, etc. In the context of education for sustainable development it is also important to reevaluate and update the arsenal of training forms and methods, which primarily should be focused on upbringing an individual with a flexible and critical thinking, creativity, capacity for reflection, and a high level of humanitarian culture - both in career activities and in social life.

This paper attempts at identifying some of the basic trends in Russian higher education in the light of the upcoming (ongoing?) transition to a new model - education for sustainable development. Special attention is paid to the trends in language education of non-philological students in the context of the described education trends.

\section{Materials and methods}

The analysis is based on numerous papers on the current state of higher education in Russia in general and linguistic education in particular, as well as papers on the transition to the model of education for sustainable development.

The key methods of study used in the paper are critical analysis of theoretical materials, followed by synthesis of the data, and reflection on our own experience in foreign language teaching as part of educational activities of the Department of business foreign language of Ural state university of economics (Ekaterinburg, Russia).

\section{Results and discussion}

\subsection{Some main trends in Russian higher education}

Total globalization as a civilization trend has covered all spheres of human activity. Thus, one of the key focuses of modern Russian higher education is its orientation on integration into the world educational space - what a number of scholars call education globalization process. Indeed, today Russia is taking an active and, what is essential, successful part in many international projects, as well as in students' and teachers' exchange. According to A. D. Ursul and T. A. Ursul, globalization as one of education megatrends in the third Millennium is not merely an important factor; indeed, it is a necessary prerequisite for an effective transition to the model of civilization sustainable development [3].

Another important trend of contemporary higher education is its focus on self-education and the principles of life-long learning. As noted by A. V. Korzhuev and V. A. Popkov, the goal of university education is not merely to 'fill' the student with a certain amount of information, but to form a cognitive strategy for self-learning as a basis and an integral part of his future labour and social activities [4]. In the modern world, where the volume of information is increasing like an avalanche, any vocational education in its traditional form will inevitably lag behind the challenges of the time and the requirements of the labour market. And it is a distinct strategy for the formation of self-learning skills in a future specialist that can bring education onto a new quality level, when a specialist is able to realize and reassess their intellectual / professional needs and adequately meet them.

The trend towards self-education and self-learning as a challenge of the time has created the need to reevaluate the methods and forms of training. So, all kinds of project technologies and search methods in the educational process are nowadays especially popular in the higher education system; they aim at forming and developing such students' skills as critical thinking, a systematic and creative approach to solving problems, etc.

The next trend in contemporary Russian higher education is the use of e-learning technologies and online learning tools. It should be noted that both were previously optional for universities and teachers who provided specific disciplines and courses, 
whereas today, in the light of the ongoing COVID 19 pandemic, any university that wants to keep up with the times and be in demand at the education services market should think about integrating online courses into the education programmes, as well as about increasing the use of e-learning tools in the teaching process. Of course, we are not talking about replacing the teacher with a computer or a presentation; we are talking about the reasonable and effective use of new technologies that are meant to replace the outdated ones.

Today, one can hear a lot of arguments about pros and cons of online learning, supporters and opponents being among both teachers and students. One of the main reasons, in our opinion, why not every Russian institution of higher education is successfully implementing the full potential of online learning, is often the teachers' lack of skill and experience, their inability to use online learning tools effectively. On that account, high-quality teacher training and retraining should become one of the priorities for Russian education authorities.

From our viewpoint, one of the obvious advantages of online learning when speaking about higher education and considering the world education development is the fact that online learning promotes students' educational mobility, and in many cases facilitates access to education, which provides the principle of equality in the light of the upcoming transition to the model of sustainable development. What is more, many types of online courses that already exist at the education services market ensure retraining and advanced training in a remote mode. On that account, online learning should be considered as an effective tool of self-learning.

Finally, the most significant trend, in our opinion, is the humanitarian focus of higher education. We should say that when speaking about the Russian higher education system, it would be more correct to call it rather a challenge of the time than a trend, since many of the related problems still need to be solved. According to the pedagogical dictionary, humanitarian focus of education is a system of measures aimed at the development of general cultural components in the content of education and thus, at the formation of students' personal maturity [5]. In the light of the upcoming transition to the model of education for sustainable development, universities of all profiles should train not just specialists who have to master an obligatory set of scientific and technical knowledge and skills, but also - and probably primarily - bearers of humanitarian ideals and values. Of course, the humanitarian focus of education cannot be limited to increasing the academic load on Humanities in technical universities. Effective humanitarian training of a future specialist implies integration of the humanitarian component into all stages and forms of the teaching process, the latter aiming at the formation of an individual who will be able to understand the values and norms of culture, to comprehend the role and value of a human in the modern world, to achieve self-determination and behave so as to ensure the principle of universal ethics and tolerance.

We should mention that just as with the use of online and electronic technologies in the educational process, the humanitarian focus of education from a simply 'smart' term is now becoming an absolute necessity for Russian universities, which are the main providers of vocational education services in the state. Thus, according to the research "Russia 2025: Resetting the talent balance" conducted by the Boston Consulting Group in 2017 from 9 to $50 \%$ of currently existing professions may disappear within ten years as a result of business processes digitalization [6]. The labour market will thus refocus on 'human in a human', that is what machines will not be able to provide: creativity, cultural and value aspects of interaction [ibid]. The humanitarian component of any education is oriented exactly on what is called 'human in a human'.

Of course, there are other tendencies and patterns that characterize contemporary Russian higher education. However, in the light of upcoming transition to a sustainable development society the abovementioned education trends in their interdependence and 
mutual influence seem to be playing the most significant part. These education trends, in our opinion, are not merely positive and essential processes in the sphere of education; they are effective tools in today's struggle with technocracy of the modern world and prerequisites for a successful and painless transition to a sustainable development society.

\subsection{Some basic principles in language education of non-philological students in the context of transition to education for sustainable development}

Speaking about the language education of non-philological students, we primarily mean the educational potential of Foreign language as an academic discipline. The humanitarian focus of education provided, the student's personality is considered the global goal and product of education. Thus, language teaching as a pedagogical issue is also characterized by a personality-centered approach. Therefore, the key concept in the contemporary strategy of foreign language teaching is the concept of a secondary (multicultural) linguistic personality. A secondary linguistic personality is understood as an individual's abilities to communicate in a foreign language at the cross-cultural level. This term was first used in the works of I. I. Khaleeva [7]. The following remark of the scholar seems to be of highly relevant: the formation of a secondary language personality is closely connected with instilling in the student a special perceptual ability to comprehend a different mentality, a different strategy and tactics of life, and therefore, a different way of interpreting information that affects any aspect of life [ibid].

Many scholars, following I. I. Khaleeva, also emphasize that teaching a foreign language as such cannot ensure an automatic formation of a secondary language personality. Thus, N. D. Galskova and N. I. Gez note that the result of teaching non-native languages to students cannot and should not be limited only to developing the linguistic competence, or teaching how to use various forms and patterns of speech [8]. The scholars emphasize that when mastering a language the one has to acquire a set of certain extralinguistic, socio-cultural knowledge, skills and abilities that characterize a native speaker as a representative of a particular linguistic and ethnic community [ibid].

Thus, the formation of a linguistic personality (both authentic and secondary) is considered nowadays as the global goal of language education and a criterion for the effectiveness of this education. Teachers and psychologists involved in the process note that today we should not be teaching a foreign language alone; we should be teaching a foreign language and a foreign culture. Therefore, we can observe an emphasis shift from exclusively pragmatic tasks in teaching a foreign language, when the latter is understood as a merely utilitarian value, to the formation of a student's ability to comprehend a different mentality, a different ideology, etc. In other words, modern language education is not only focused on the formation and development of the learner's ability to practically use the language in various communicative contexts (i.e. communicative skills development), but also on familiarization of learners with a different (national and cultural) way of thinking, a different language picture of the world. In this regard, as N. D. Galskova and N. I. Gez state, it would be more correct to speak about a linguocultural education rather than about a language education [ibid].

Such understanding of the purpose of foreign language teaching fully corresponds to the principles and patterns of the abovementioned humanitarian focus of higher education. Familiarization with the picture of the world of a different linguistic and cultural community, the formation of the so-called 'transcultural consciousness' [9] as the global goal of language education is inextricably linked with the development of such students' qualities as racial, ethnic, religious and socio-cultural tolerance, which are meant to become the key to successful, conflict-free communication both at the internal and international level. 
Returning to the specifics of higher education, we should say that the general didactic learner-centered approach in foreign language teaching does not contradict the competencybased approach adopted in Russian higher education. The competency-based approach is reflected in Federal state education standards and basic vocational education programmes as a set of universal, supra-professional, and professional competencies (hard skills). It seems obvious that the potential of Foreign language as an academic discipline for nonphilological students primarily consists in forming and developing universal and supraprofessional competencies, many of which are often called 'soft skills' or 'skills of the XXI century'. In contrast to 'hard skills', which stand for specific professional knowledge, skills and abilities related to the performance of certain labour functions (in this sense, foreign language proficiency can also be considered as a hard skill), soft skills are those competencies that are necessary for every human and every successful specialist, regardless of the education profile. Soft skills primarily include managerial and communication skills - the skills of multicultural interaction and dialogue, effective decision-making and conflict resolution, creative problem solving and some others.

Today, according to most methodologists and educators, one of the most effective means of forming and developing soft skills in a future specialist and thus, creating a humanitarian-focused educational environment is to initiate 'a productive mode of linguistic education' [10] and thus, ensure 'productive academic activity of a student' [ibid].

Some of the specific productive forms and technologies of learning, which are intensively and successfully applied by the teachers of the Department of business foreign language (USUE, Ekaterinburg) include interactive technologies (role play, dramatization, discussion, debate); project methods involving search objectives and creation of a personally important product (digital stories, multimedia presentations, videos etc.); students' research activities (writing papers and preparing reports for research conferences and linguistic competitions, etc.). To introduce a scientific and practical component in the process of foreign language learning the Department of business foreign language also holds an annual student conference "Russia in the Global World: Challenges of the 21st Century", which welcomes students from various higher education institutions of the country, as well as students of four USUE education profiles - Information Technologies, Management, Economics and Human Resources. Undoubtedly, such conferences contribute a lot to increasing students' motivation to learn a foreign language and their interest in research activities. And what is no less important is that such conferences ensure the humanitarian-focused vocational training of a future specialist, since a foreign language turns from one of the goals of education into an effective tool of understanding the world around us and an instrument of social and professional activities. Thus, in the global context, the productive mode of linguistic education is meant to contribute to the formation of an individual with a clear and creative thinking, willing and capable of living in a sustainable world.

\section{Conclusions}

Thus, in its modern development paradigm, the contemporary Russian higher education, in order to make an effective transition to the new model of education for sustainable development, should be focused on the humanitarian values and ideals of civilization, on global goals and priorities of the sustainable world. On that account, foreign language teaching is becoming a significant component of the humanitarian basis of a future specialist of any profile, the creative, productive mode of learning being of particular importance. This approach proves to be highly effective in the development of universal, professional and supra-professional skills, which in their turn facilitate self-realization of an individual both in labour and social frameworks. 


\section{References}

1. Education for Sustainable Development, https://en.unesco.org/themes/educationsustainable-development

2. I. V. Ilyin, A. D. Ursul, T. A. Ursul, Vestnik of MSU, 2, 3 (2017)

3. A. D. Ursul, T. A. Ursul, Future Human Image, 3, 39 (2014)

4. A. V. Korzhuev, V. A. Popkov, Traditions and innovations in higher professional education (2003)

5. Pedagogical terminological dictionary, https://pedagogical_dictionary.academic.ru/

6. K. Polunin, A. Stepanenko, E. Sycheva, Russia 2025: Resetting the talent Balance (2017)

7. I. I. Khaleeva, Secondary language personality as a recipient of a foreign language text (1995)

8. N. D. Galskova, N. I. Gez, The theory of foreign languages teaching (2006)

9. E. V. Potemkina, Vestnik of LSU named after A. S. Pushkin, 2, 215 (2013)

10. N. F. Koryakovtseva, Vestnik of MSLU, 1, 33 (2016) 